American Journal of Agricultural and Biological Science 1 (1): 22-26, 2006

ISSN: $1557-4989$

(c) 2006 Science Publications

\title{
Microbial Population In Decompsing Legume Litter Of Differing Quality
}

\author{
${ }^{1}$ M.B. Oyun, ${ }^{2}$ Akharayi, F.C. and ${ }^{2}$ Adetuyi, F.C. \\ ${ }^{1}$ Department of Forestry and Wood Technology, ${ }^{2}$ Department of Microbiology \\ Federal University of Technology, P.M.B. 704, Akure, Nigeria
}

\begin{abstract}
The influence of litter quality on microbial population during decomposition of fresh pruning of Acacia auriculiformis; Gliricidia sepium and Acacia mixed with Gliricidia (50:50) is reported. Acacia (soluble $\mathrm{C}, 46.6 \%$; N, 3.9\%; Phenolic, $2.3 \%$ ) was rated as low quality litter while Gliricidia (soluble C, $45.2 \%$; N, 4.8\%; Phenolic, 2.3\%) was rated as high quality litter. Acacia mixed with Gliricidia (50:50) had an initial phase of rapid decomposition followed by a second phase of comparatively lower decomposition rate. Acacia litter showed only a single phase of decomposition. Bacteria population increased linearly with nutrient content that was immobilized during decomposition, while fungal population varied more with litter type than with different phases of decomposition. Generally, the bacteria population isolated from Acacia-Gliricidia mixture was highest, followed by Gliricidia while it is lowest in Acacia, however more fungal population were isolated from Acacia litter than Gliricidia litter in all the phases of decomposition.
\end{abstract}

Key words: Bacteria, fungi, population, decomposition rate, litter quality

\section{INTRODUCTION}

Both economic and environmental concerns have led to a renew interest in legume residues as a source of nitrogen in agricultural systems. In order to optimize the use of legume for subsequent or companion crop, it is necessary to be able to estimate accurately their mineralization rate after being incorporated into the soil. The main drive in research has been to find ways of predicting the rate of litter decomposition and rate of nutrient release from the chemical composition of the resource $^{[1]}$. The rate of decomposition of any resource (leaf, fruit, twig, root and faecal pellet) available to microorganisms is controlled by the physico-chemical environment and its intrinsic properties (resource quality). The term resource quality embraces those intrinsic properties of a resource, which determine the activities of decomposer organisms in a specific way. Lignin can act both as a carbon and energy source as well as a modifier.

Consequently, together with nutrient concentration, it is key component of resource quality. A variety of predictive equations have been proposed, mainly using various ratios of carbon, nitrogen, lignin and polyphenol $^{[2]}$. The relationships between these resource quality characteristics and decomposition rates are largely empirical and there is still poor understanding of the interactions of the biochemical constituents of litter at the cellular level where microbial decomposition takes place. However, Berendse ${ }^{[3]}$ expressed explicit relationships between litter decomposition, mass loss and microbial growth in a theoretical model. The model considers the relative importance of lignin, carbohydrates masked by lignin and free carbohydrates in relation to nitrogen. A negative relationship of mass loss to lignin concentration is predicted and a positive relationship to initial nitrogen concentration when it is limiting microbial growth. The model realistically simulates various field data for forest litters, but indicates the limitations of available chemical, as well as microbial information. The role of soil micro-fauna in turnover of high quality litter is relatively minor, but becomes increasingly important with low quality litter. A more diverse soil fauna community leads to accelerated early decomposition, but has little effect on the final extent of decomposition rates in agricultural systems.

The present study investigates the influence of litter quality on the microbial population during decomposition so as to provide the much-needed information on the relationship between biochemical constituents of litter and microbial growth as decomposition progresses.

\section{MATERIALS AND METHODS}

Experimental site and legume tree species: The experiment was carried out in the plantation site of the Department of Forestry and Wood Technology, Akure, Nigeria. The tree legumes were established in 1984 on a $10 \mathrm{~m} \times 10 \mathrm{~m}$ plots. The species include Acacia auriculiformis, Gliricidia sepium, Dalbergia latifolia, Acacia cracicarpa and Albizia zygia. Non-legume tree species, which include Gmelina arborea, Tectona grandis and Eucalyptus camaldulensis, were also established alongside with the tree legumes.

Corresponding Author: M.B. Oyun, Department of Forestry and Wood Technology, Federal University of Technology, P.M.B. 704, Akure, Nigeria 
Characterisation of litter quality: Prior to decomposition of litter, total nitrogen, soluble carbon and polyphenolic contents of fresh leaf samples of the legume trees species were determined in the laboratory. Nitrogen and polyphenolic contents were extracted in hot $\left(80^{\circ} \mathrm{C}\right)$ aqueous methanol. Total $\mathrm{N}$ was determined by Kjedahl method while polyphenol was determined colorimetrically using Folin-Ciocalteau reagent with tannic acid as standard. Soluble carbon was determined as soluble carbohydrate ${ }^{[4]}$.

The initial chemical properties of mulch were analysed on three samples of the species used.

Decomposition study: Two legume tree species with differing litter qualities, which include Acacia auriculiformis (low litter quality) and Gliricidia sepium (high litter quality) were selected randomly for collecting leaf sample. The collection was made from each selected tree at $5 \mathrm{~m}$ from the ground level. Composite samples were made from collections obtained from ten trees per species so as to ensure that natural field variability is included in the sampling technique $^{[5]}$. One hundred gram of each composite was weighed and placed in a polyphenol litterbag of size $20 \mathrm{~cm} \times 20 \mathrm{~cm}$ with $7-\mathrm{mm}$ mesh at three replicates. It was assumed that the use of litterbags with 7-mm openings would give results comparable to changes occurring in unconfined litter. The treatments include:

* $100 \mathrm{~g} \mathrm{bag}^{-1}$ (Acacia mulch),

* $\quad 100 \mathrm{~g} \mathrm{bag}^{-1}$ (Gliricidia mulch),

* $\quad 100 \mathrm{~g} \mathrm{bag}^{-1}$ (Acacia + Gliricidia:50 : 50 wt. Basis).

Fifteen bags per treatment were placed on the field in the plantation site in a completely randomized design (CRD).

At $0,4,8,16,32$ and 64 days, three bags per treatment were retrieved from the field and transferred to the laboratory to assess the microbial population of the decomposed litter. The bags were carefully lifted at each sampling period to reduce losses of particulate material.

Microbial count and identification: Sub-samples (1g) of each residues collected were placed in oven sterilized conical flasks and $20 \mathrm{ml}$ of distilled water added. The flasks were shaken thoroughly and allowed to stand for 20 minutes. Each suspension $(1 \mathrm{ml})$ was serially diluted in test tubes containing $9 \mathrm{ml}$ of distilled water in test tube. For day 0 and 4 during decomposition, $10^{-4}$ dilution was used for microbial count while $10^{-6}$ dilution was used for microbial count at $8,16,32$ and 64 days. One milliliter of solution was pipetted into a set of Petri dishes and were overlaid with $20 \mathrm{ml}$ of POA incorporated with $20 \mathrm{ml}$ streptomycin to eliminate bacteria. The plates were gently swirled to evenly mix up and allowed to gel. They were thereafter incubated for $18-24$ hours and 72 hours at $25^{\circ} \mathrm{C}$ in inverted position in two different incubators sterilized with potassium permanganate and formaldehyde for bacteria and fungi respectively.
Colonies which developed after incubation were counted using Gallenkamp colony counter. The colonies were sub-cultured to obtain pure isolates. The pure isolates of bacteria were aseptically transferred into nutrient agar while those of fungi were transferred on to potato dextrose agar slants and incubated. When growth developed, the slants were preserved in the refrigerator at $5^{\circ} \mathrm{C}$ for further studies and identification to species level ${ }^{[6]}$.

Morphological identification, physiological and biochemical tests for characterization of the isolates were carried out to species level using the method described by Cowan ${ }^{[6]}$.

Statistical analysis: The bacteria and fungi counts in decomposed material were analysed by ANOVA for a completely randomised design (CRD) to determine significance of differences $(\mathrm{P}>0.05)$ between the treatments. Least significant difference (LSD) was further used to separate the means. For decomposition rate, a single exponential model, $\mathrm{Y}_{\mathrm{t}}=\mathrm{Y}_{\mathrm{a}} \mathrm{X}_{\mathrm{e}}=\mathrm{kt}$ (where $Y_{a}$ is the original amount of material applied and $Y_{t}$ is the proportion of the initial dry matter remaining after a period of time, $t$, in days) was fitted. A. plot of time against logarithm $(\log )$ of this first-order exponential model was made for each replicate. Microbial population was correlated with rate of litter decomposition.

\section{RESULTS}

Climatic data: During the course of the study (September and October, 2004) daily maximum temperature and precipitation records were recorded at the weather station, Federal University of Technology, Akure, Nigeria (Table 1).

Litter quality characteristics: The chemical composition of the selected legume litter is shown in Table 2. Based on the result of the chemical analysis of the relevant contents, Acacia auriculiformis was rated as having low quality litter with $46.6 \%$ soluble carbon and $14.4 \%$ phenol while Gliricidia sepium was rated as high quality litter.

Patterns of litter decomposition: With the exception of Acacia litter, Gliricidia litter and Gliricidia mixed with Acacia $(50 ; 50)$ litter had an initial phase of rapid decomposition followed by a second phase of comparatively lower decomposition rate. Acacia litter showed only a single phase of decomposition.

Comparatively higher decomposition rate than Acacia and lower decomposition rate than Gliricidia was observed in Acacia mixed with Gliricidia (Fig. 1).

Effect of litter type on bacteria and fungi population: Bacteria and fungi counts are negatively correlated with percentage decomposition of litter 
Am. J. Agri. \& Biol., 1 (1): 22-26, 2006

\begin{tabular}{|c|c|c|c|}
\hline Month & Mean Temperature $\left({ }^{\circ} \mathrm{C}\right)$ & Mean Relative Humidity (\%) & Mean Rainfall (mm) \\
\hline September & 24.5 & 84 & 6.5 \\
\hline October & 24.1 & 82.3 & 7.6 \\
\hline \multicolumn{4}{|c|}{ Source: Department of Meteorology, Federal University of Technology, Akure } \\
\hline Legume Species & \% Soluble Carbon & $\% \mathrm{~N}$ & $\%$ Phenolic (TAE) \\
\hline Acacia auriculiformis & 46.6 & 3.9 & 14.4 \\
\hline Gliricidia sepium & 45.2 & 4.8 & 2.3 \\
\hline
\end{tabular}

Table 3: Correlation coefficients associating litter decomposition (5) and microbial population

\begin{tabular}{llll}
\hline & \% Decomposition & Bacterial Count & Fungal Count \\
\hline \% Decomposition & 1 & & \\
Bacterial count & -0.6325 & 1 & 1 \\
Fungal count & -0.5421 & 0.8047 & 1 \\
\hline
\end{tabular}

Table 4: Mean total count of bacterial and fungi in a decomposing litter of Acacia auriculiformis, Gliricidia sepium and Acacia + Gliricidia mixture $(50: 50) *$

\begin{tabular}{|c|c|c|c|c|c|c|c|c|c|c|c|c|}
\hline Decomposition Pe & & & & & & & & & & & & \\
\hline \multirow[b]{2}{*}{ Litter type } & \multicolumn{2}{|l|}{0 day } & \multicolumn{2}{|l|}{4 days } & \multicolumn{2}{|l|}{8 days } & \multicolumn{2}{|l|}{16 days } & \multicolumn{2}{|l|}{32 days } & \multicolumn{2}{|l|}{64 days } \\
\hline & $\mathrm{BC}$ & $\mathrm{FC}$ & $\mathrm{BC}$ & FC & $\mathrm{BC}$ & FC & $\mathrm{BC}$ & $\mathrm{FC}$ & $\mathrm{BC}$ & FC & $\mathrm{BC}$ & FC \\
\hline $\begin{array}{l}\text { Acacia } \\
\text { auriculiformis }\end{array}$ & $136.6 \mathrm{a}$ & $7.0 \mathrm{a}$ & $160.3 a$ & $20.0 \mathrm{a}$ & $251.3 \mathrm{a}$ & $14.3 \mathrm{ab}$ & $271.0 \mathrm{a}$ & $20.6 \mathrm{ab}$ & $254.6 \mathrm{a}$ & $24.6 \mathrm{a}$ & $126.6 \mathrm{a}$ & $29.3 \mathrm{ab}$ \\
\hline $\begin{array}{l}\text { Gliricidia sepium } \\
\text { Acacia-Gliricidia }\end{array}$ & $154.0 \mathrm{a}$ & $11.3 \mathrm{a}$ & $253.3 b$ & $21.3 b$ & $310.0 \mathrm{a}$ & $12.0 \mathrm{a}$ & $640.0 \mathrm{~b}$ & $18.6 \mathrm{a}$ & $622.0 \mathrm{~b}$ & $19.3 \mathrm{a}$ & $427.0 \mathrm{~b}$ & $21.0 \mathrm{a}$ \\
\hline mixture $(50: 50)$ & $263.0 \mathrm{a}$ & $11.0 \mathrm{a}$ & $352.0 \mathrm{c}$ & $25.0 \mathrm{a}$ & $470.6 \mathrm{~b}$ & $36.6 \mathrm{ab}$ & $769.6 \mathrm{~b}$ & $48.6 \mathrm{ab}$ & $901.6 \mathrm{c}$ & $51.0 \mathrm{~b}$ & $1130.3 \mathrm{c}$ & $55.6 \mathrm{ab}$ \\
\hline
\end{tabular}

* Data in a column followed by the same letter are not significantly different according to LSD (P>0.05) BC: Bacteria count, FC: Fungi count

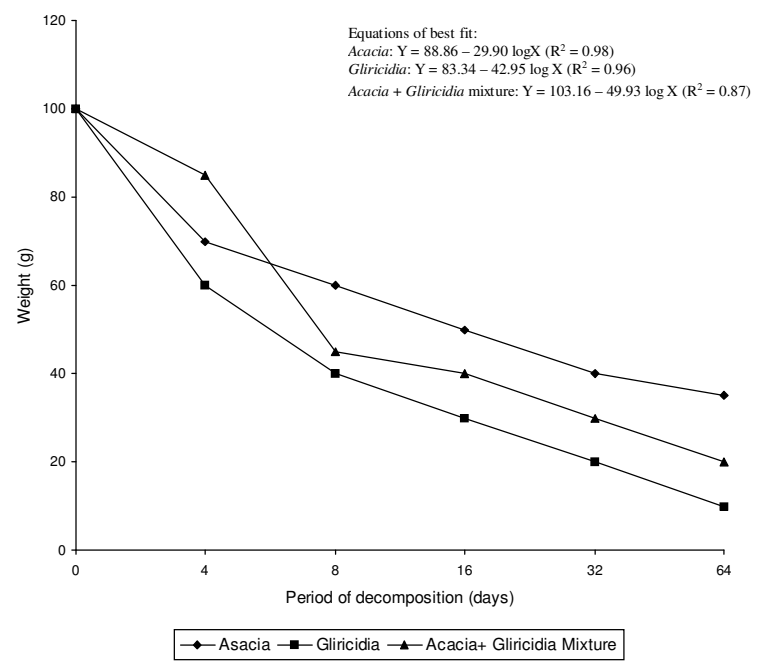

Fig. 1: Rate of litter decomposition of Acacia auriculiformis, Gliricidia sepium and Acacia + Gliricidia mixture (50: 50)

(Table 3). The bacteria count in the fresh pruning of Acacia $\left(136 \mathrm{cfu} \mathrm{g}^{-1}\right)$ and Gliricidia $\left(154 \mathrm{cfu} \mathrm{g}^{-1}\right)$, were not significantly different before decomposition. However, the bacteria counts of $263 \mathrm{cfu} \mathrm{g}^{-1}$ in Acacia mixed with Gliricidia (50:50) compared to Acacia and Gliricidia were significantly different according to LSD $(\mathrm{P}>0.05)$ (Table 4). The fungal count in all the litter types was not significantly different before the start of decomposition.

At 4, 32 and 64 day of decomposition, the respective bacteria counts in Acacia $(160.3,254.6,126.6$ cfu $\left.\mathrm{g}^{-1}\right)$, Gliricidia (50:50) $\left(353,901,1130 \mathrm{cfu} \mathrm{g}^{-1}\right)$ were significantly different. The fungal counts on day 4 were not significantly different among the three litter types. At day 32 after decomposition, there were no significant difference in the fungal count between Acacia $\left(24.6 \mathrm{cfu} \mathrm{g}^{-1}\right)$ and Gliricidia $\left(19.3 \mathrm{cfu} \mathrm{g}^{-1}\right)$ litter but these were significantly different from Acacia mixed with Gliricidia $\left(51.0 \mathrm{cfu} \mathrm{g}^{-1}\right.$ ). At day 64 after decomposition, the fungi counts in Acacia litter (29.3) and Acacia mixed with Gliricidia (55.6) were not significantly different. However these were significantly different from fungi count Gliricidia litter $\left(21.0 \mathrm{cfu} \mathrm{g}^{-1}\right)$.

At day 8 after decomposition, the bacteria counts in Acacia litter $\left(251.3 \mathrm{cfu} \mathrm{g}^{-1}\right)$ and Gliricidia litter (310.0 $\mathrm{cfu}^{-1}$ ) are not significantly different from the counts in Acacia + Gliricidia mixture $\left(470.6 \mathrm{cfu} \mathrm{g}^{-1}\right)$. The fungi counts in Acacia litter $\left(14.3 \mathrm{cfu} \mathrm{g}^{-1}\right)$ and Acacia mixed with Gliricidia mixture $\left(36.6 \mathrm{cfu} \mathrm{g}^{-1}\right)$ were not significantly different but were significantly different from Gliricidia litter $\left(12.0 \mathrm{cfu} \mathrm{g}^{-1}\right)$.

At day 16 after decomposition, the bacteria count in Gliricidia litter $\left(640 \mathrm{cfu} \mathrm{g}^{-1}\right)$ and Acacia mixed with Gliricidia mixture (769.6 $\mathrm{cfu} \mathrm{g}^{-1}$ ) were not significantly different but were significantly different from the counts in Acacia litter $\left(271 \mathrm{cfu} \mathrm{g}^{-1}\right)$.

\section{DISCUSSION}

Decomposition and nutrient release patterns of organic materials are determined by the nutrients of the material, the decomposing organism present and the environmental conditions. The relative importance of 
each of these biological or environmental control system was reviewed by Swift $^{[7]}$ where he introduced the concept of resource quality to convey the chemical and physical composition of organic material that influence the rate of decomposition.

Aber and Melillo ${ }^{[8]}$ further differentiated the effects of organic constituents and carbon quality from that of nutrient content and nutrient quality on decomposition. As shown by the result of this study, the litter types involved in the decomposition studies differ markedly in quality and hence in organic and nutrient contents. This culminates to rapid ate of decomposition in Gliricidia sepium than Acacia auriculifirmis, which tends to be more recalcitrant to microbial attack and hence reduced rate of decomposition.

The recalcitrant nature of $A$. auriculiformis litter to microbial attack at the initial stage of decomposition can be attributed to a very high phenolic content in the leaf (14.4\% TAE). Litter quality undoubtedly regulates the potential rate and outcome of decomposition. Thus the higher rate of decomposition and microbial population in Acacia mixed with Gliricidia (50:50) than sole Acacia litter and lower rate of decomposition than sole Gliricidia suggest that a better efficiency of litter use could be achieved through such litter manipulation in agricultural systems. However, the actual rate and extent of decomposition is moderated by the activity of the decomposing organisms and the environmental conditions $^{[1]}$. The results showed that microbial population during litter decomposition varies as decomposition progressed. The general trend seems to suggest that bacteria population increase linearly with nutrient content that is immobilized during decomposition. This assumption agrees with the earlier indication by Giller and $\mathrm{Cadisch}^{[1]}$ that nitrogen is one of the commonest factors limiting litter decomposition as it determines the growth and turnover of the microbial biomass mineralizing the organic carbon. It was observed that the bacteria population isolated from Acacia auriculiformis was low compared to that from Gliricidia sepium few days after the start of decomposition. But the bacteria population increased as decomposition progressed, which coincide with increased mineralization rate from the recalcitrant litter. On the other hand, bacteria population isolated from the Gliricidia litter was high initially and declined gradually as decomposition progressed. This is because Gliricidia decomposed rapidly after few days of decomposition and released the bulk of the nutrients, but this diminished later as decomposition progressed. The study by Van Wensen et al. ${ }^{[9]}$ had indicated earlier that microbial, particularly fungal, successions on decomposing litters reflect changes in litter decomposition as do fauna with recognition of phases in palatability and interaction with micro flora.

The results show that fungal population varies more with litter type than with the different phases of decomposition. This finding corroborate earlier studies by Couteaux et $a l .^{[10]}$ which suggested that fungi are more strongly influenced by substrate quality whereas bacteria populations are largely regulated by predation. As pointed by Couteaux et al. ${ }^{[10]}$, the role of soil fauna in turnover of high quality litter is relatively minor, but becomes increasingly important with low quality litter.

A more diverse soil fauna community leads to accelerated early decomposition, but has little effect on the final extent of decomposition and this may be of relevance in regulating decomposition rates in agricultural systems. Species of gram positive and gram-negative cocci and rods and fungi of different species were the organisms responsible for the decomposition of the legume leaves. The peak of decomposition was between day 8 and day 16 during which some arthropods of different kinds such as earthworms, woodlice and termites were observed. This could be responsible for the high bacteria population recorded at this period because the actions of these macro-organisms exposed the leaf surfaces for easy attack by microorganisms thereby creating an assess for microorganisms to thrive well and rapidly multiply. The decline in bacteria population after day 16 except for the legume mixture could be as a result of reduction in nutrient from the litter and the gradual increase in fungal population that might have inhibitory effect on some of the bacteria.

\section{CONCLUSION}

In this study, the litter types differ markedly in quality and hence in organic and nutrient contents. Acacia auriculiformis was more recalcitrant to decomposition while Gliricidia sepium and AcaciaGliricidia mixture (50:50) decomposed more rapidly within few weeks of decomposition.

Furthermore, microbial population particularly bacteria, varied more with nutrient contents in the litter and not necessarily with organic and carbon content (litter quality). Also it is clear that most of the micro-organisms responsible for litter decomposition are air-borne and are found readily on the fresh litter even before the start of decomposition. It is further demonstrated that organic constituents in the litter directly influenced the rate of decomposition, which indirectly regulated the microbial population, for further attack on the litter.

This study gives a progress report beyond mere descriptive studies of decomposition. There are some studies $^{[5,11]}$ that reported mass loss during decomposition in the absence of plant quality, climate and microbial data that are needed for explaining the process and modeling purposes. It is high time that studies of decomposition proceed beyond descriptive to predictive phase. 


\section{REFERENCES}

1. Giller, K.E. and G. Cadisch, 1997. Driven by Nature: A sense of Arrival or Departure? CAB International, Driven by Nature Plant Litter Quality and Decomposition (Eds. Cadisch, G. and K.E. Giller), pp: 393-399.

2. Myers, R.J.K., m. Van Noordiwijk and P. Vityakon, 1997. Synchrony Of Nutrient Release And Plant Demand: Plant Litter Quality, Soil Environment \& Farmer Management Options. CAB International Driven by Nature Plant Litter Quality and Decomposition (Eds G. Cadisch and K.E. Giller), pp: 215-229.

3. Berendse, F., B. Berg and E. Bosatta, 1987. The effect of lignin and nitrogen on the decomposition of litter in nutrient-poor ecosystems: A theoretical approach. Can. J. Bot., 65: 116-1120.

4. Dubois, M., K.A. Gilles, J.K. Hamilton, P.A. Rebers and F. Smith, 1956. Colorimetric method of determination of sugars and related substances. Anal. Chem., 28: 350-356.

5. Palm, C.A. and P.A. Sanchez, 1991. Nitrogen release from the leaves of some tropical legumes as affected by their lignin and polyphenolic contents. Soil Biology and Biochemistry 23 [1] : 83-88
6. Cowan, S. and K.J. Steel, 1977. Manual for the Identification of Medical Bacteria. 4th Edn. Cambridge University Press, pp: 22-29.

7. Swift, M.J., O.W. Heal and J.M. Anderson, 1979. Decomposition in Terrestrial Ecosystem. Blackwell Scientific Publications, Oxford, pp: 372.

8. Aber, J. and J. Melillo, 1991. Nitrogen mineralization in decaying hardwood leaf litter as a function of initial nitrogen ad lignin content. Can. J. Bot., 60: 2263-2269.

9. Van Wensen, J., H.H. Verhoef and N.M. Vanstraalen, 1995. Litter degradation stage as a factor for isopod interaction with mineralization processes. Soil Biol. Biochem., 25: 1175-1183.

10. Couteaux, M.M., M. Mousseau, M.-L. Celerier and P. Bolther, 1991. Increased atmosphere $\mathrm{CO}_{2}$ and litter quality: Decomposition of sweet chestnut leaf with animal food webs of different complexities Oikos, 61: 54-64.

11. Yamoah, C.H., A.A. Agboola and K. Mulongoy, 1986. Decomposition, nitrogen release and weed control by pruning of selected alley cropping shrubs. Agroforestry Systems, 4: 234-246. 